体育・スボーツに於ける経済学的分析（そのI）

スボーツ・クラフでの経済的諸問題

1II. 学生スボーシマンの学力 (学習能力) 及び 性格

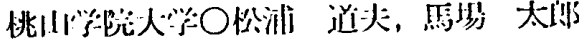

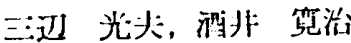

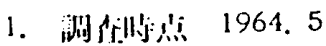

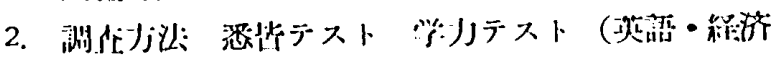
一入”:

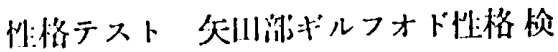
垈.

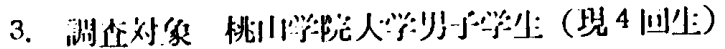
459 色

グルーブ利

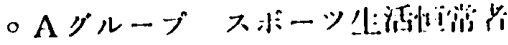

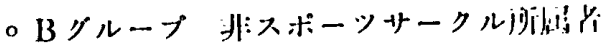

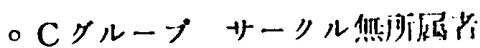

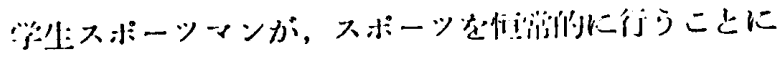

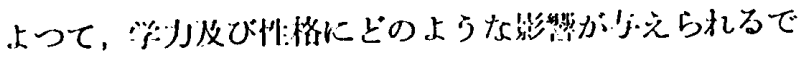
あうるか。

(I) 学生スボーツマンの学力推移

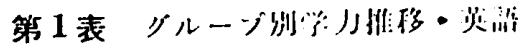

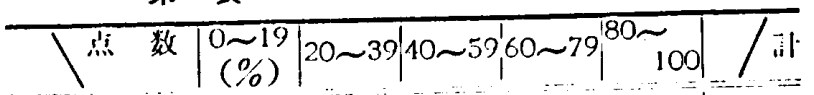

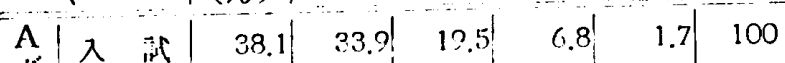

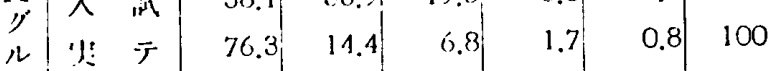

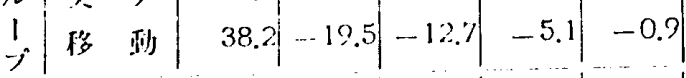

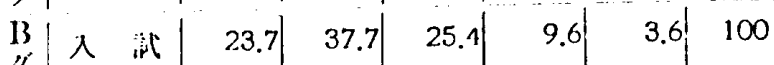

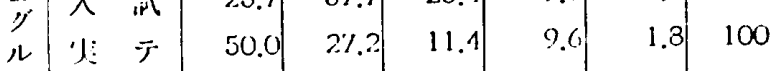

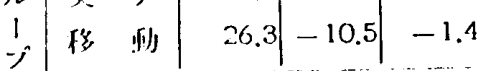

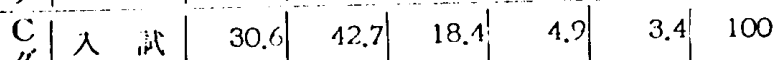

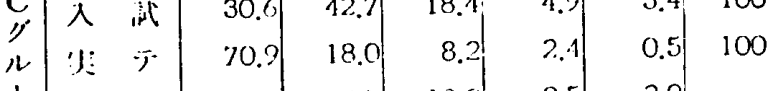

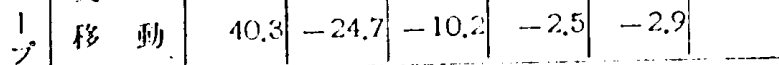

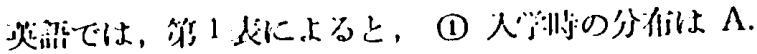

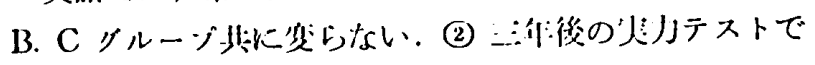

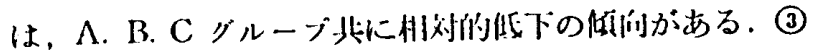

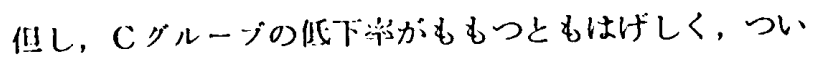

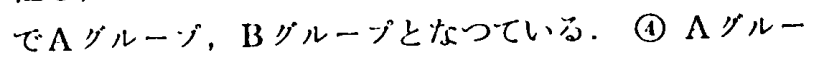

プはCグループよりは兴翼能为がよい。しかし，現状で はBグループがむつともよい。

スポーツ领域别では，(1) 入管得はやや格技系がよく，

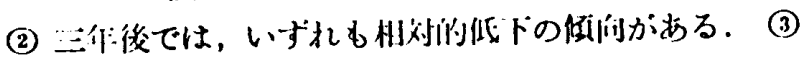
その机，球技系がもつをよく，ついで格发系，その 他ゴフ，ボーリング䈍) となつている.

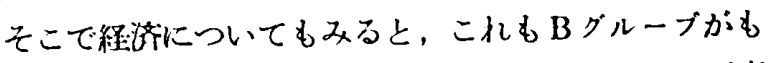
つともよく、Aグループ，Cグループは拱にはとんと变 らない.

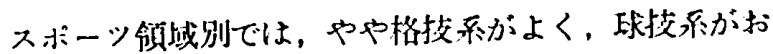
とるようである。

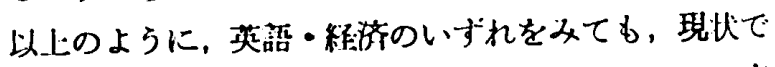

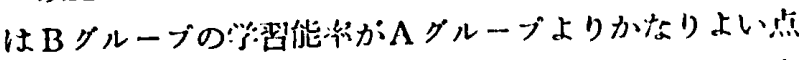

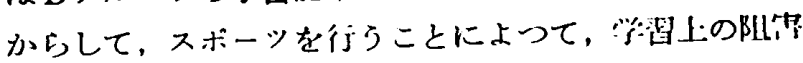

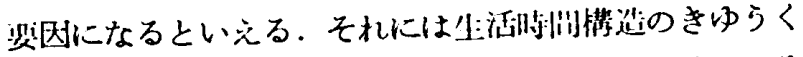

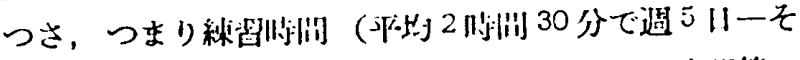

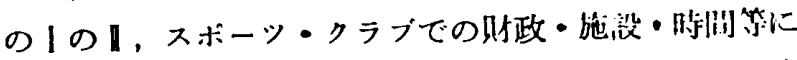
つて）や，恐川施没の不足からくる交通に界与る脚

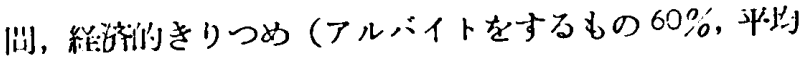

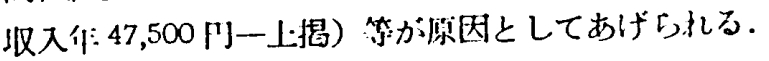

\section{(II) 学生スボーツマンの性格特徽}

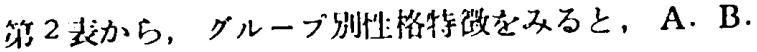

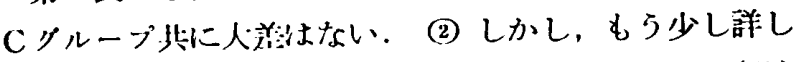

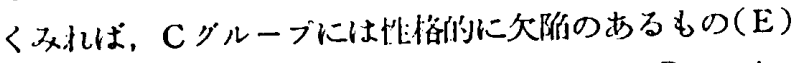
がやや多く，Aグルーブはもつとも少ない（3） Cグル ーブは，A． Bグルーブにくらへて，理想的なタイプ (D) が少ない.

次にスポーツ领域别では，(1) 格技科俚球技乔にくら

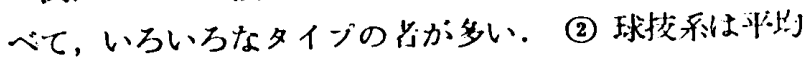

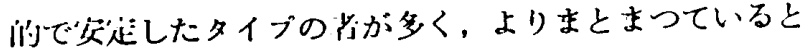
い方る。

(III) 結

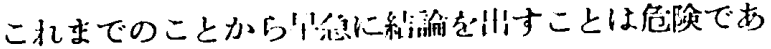
るが，スポーツッークルに眼することは，兴習上の阻

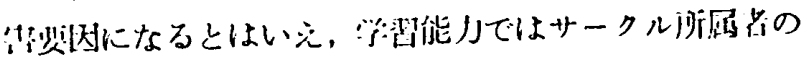
ほうがよく，性格の通でもサークル所屈者のほうが好ま しいよいえる.つまり们もしないでいる（サークル阶属 しないでいる）よりは，何らかのサークルに所属したは らかよいと思われて。

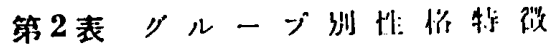

\begin{tabular}{|c|c|c|c|c|c|c|c|c|c|c|c|c|c|c|c|c|c|c|}
\hline & $\left(\begin{array}{c}A \\
(\%)\end{array}\right.$ & $\Lambda \mathrm{B}$ & $\mid \begin{array}{lll}\mathrm{A} & \mathrm{B} & \mathrm{F}\end{array}$ & $\Lambda \mathrm{C}$ & $\mathrm{AE}$ & $\mathrm{AF}$ & B & C & $\mathrm{CD}$ & $\mathrm{CDF}$ & D & D A & $\left|\begin{array}{ll}D & B\end{array}\right|$ & DF & $E$ & E F & $F$ & / it \\
\hline A グルーブ & 20 & 7.2 & 0 & 1.4 & 0 & 0 & 3.6 & 0 & 0.7 & 0 & 61.4 & 0 & 0 & 0.7 & 4.3 & 0.7 & 0 & 100 \\
\hline B グループ & 20.1 & 3.5 & 0.9 & 0 & 0 & 0.9 & 0.9 & 0.9 & 0 & 0.9 & 62.2 & 0 & 0 & 1.8 & 7.9 & 0 & 0 & 100 \\
\hline Cグループ & 29 & 4 & 1 & 1.5 & 0.5 & 0.5 & 1.5 & 1 & 0 & 0 & 47.5 & 0.5 & 0.5 & 1 & 11 & 0 & 0.5 & 100 \\
\hline
\end{tabular}

